\title{
Assessing the Education and Training Strategy of Selected Colleges Responding to the Needs of Highly Qualified Professional
}

\author{
Vu Quach ${ }^{1}$, Nhan Hoang Vo ${ }^{2}$ \& Cuong Hung Pham ${ }^{3}$ \\ ${ }^{1}$ Ca Mau Community College, Vietnam \\ ${ }^{2}$ University of Medicine Pham Ngoc Thach, Vietnam \\ ${ }^{3}$ Foreign Trade University, Ho Chi Minh City Campus, Vietnam \\ Correspondence: Nhan Hoang Vo, University of Medicine Pham Ngoc Thach, \#86/2 Thanh Thai, District 10, Ho Chi \\ Minh City, Vietnam.
}

Received: April 14, 2016

Accepted: May 4, 2016

Online Published: May 13, 2016

doi:10.5430/ijfr.v7n3p81

URL: http://dx.doi.org/10.5430/ijfr.v7n3p81

\begin{abstract}
The study of Assessing the education and training strategy of selected colleges responding to the needs of highly qualified professional conducted during the period from 5/2013 to 10/2015. The research result showed that there were 400 studentsof $\mathrm{Ca}$ Mau Community College (CCC) interviewed and answered nearly 18 questions. The researcher had analyzed KMO test, the result of KMO analysis used for multiple regression analysis. Studentsare responses measured through an adapted questionnaire on a 5-point Likert scale. Hard copy and interviewstudentsby questionnaire distributed among studentsof $\mathrm{Ca}$ Mau Community College. The regression analysis result showed that there were three factors, which included of factors followinglecturer, facilities, and programsaffecting the education and training quality at $\mathrm{Ca}$ Mau Community College with significance level of $5 \%$. In addition, the research result processed from SPSS 20.0 software. The parameters of the model estimated by Least - Squares Method tested for the model assumption with 5\% significance level. At the same time, the result was also scientific evidence and important for researchers, and policy makers who apply them for developing the education and training quality at $\mathrm{Ca} \mathrm{Mau}$ Community College.
\end{abstract}

Keywords: education and training strategy, colleges, needs of highly qualified professional

\section{Introduction}

$\mathrm{Ca}$ Mau, which is located in Mekong River Delta, is a coastal province in the southernmost of Vietnam. It lies on Ca Mau Peninsula and shares border with KienGiangprovince to the North, Bac Lieu province to the east, the East Sea to the east and the south, the Gulf of Thailand to the west. Ca Mau has a coastline of 254 kilometres long and belongs to the eastern coastal corridor of the Southwestern waters (Bac Lieu, GanhHao, Ca Mau, Nam Can). The total value of goods and service retail reached 21,600 billion VND in 2012, and was estimated to reach 28,000 billion VND in 2013, a 30\% increase annually. The export turn-over reached US\$ 640 million in 2012, and was estimated to reach US\$ 720 million in 2013. To build a prosperous society, every country should be based on the synergy of the resources inside and outside, in power including the foundation of inner resources that are particularly important and significant human resource decisions. In the trend of globalization, the development of the knowledge economy with modern technology requires human resources to be able to dominate science and high technology can ensure the sustainable development. Training human resources is a strategic task of leading importance in each country. Abundant human resources, but must have the qualifications, competence, new qualities can master all areas, implement national goals and contribute to the international community. Ca Mau also needs to promptly finalize planning for socio-economic development, improve the investment environment to attract enterprises, and boost equalization of businesses as well as combat illegal trafficking, trade fraud and counterfeit goods, he requested.Ca Mau has been urged to exert continuing efforts to renovate and further the quality of reward and emulation activities, aiming to ensure accuracy, timeliness, fairness and objectivity.

\section{Lierature Review}

The training quality has been defined in many different ways. However, various researchers have shared their findings regarding trainees' views and concernsabout quality and regarding the use of students to measure the quality 
of services provided. As Gold (2001) argues, traineesshould be considered as primary customers and educational institutions should focus their efforts on improving trainees-centered education. Trainees should be assessed as the product of the institution (Emery et al., 2001).

The effectiveness of a training program may vary as afunction of the criteria chosen to measure effectiveness (Arthur, Tubre, et al., 2003). Thus, it is reasonable to ask whether theeffectiveness of training - operationalized as effect size dsvariessystematically as a function of the outcome criterion measureused. For instance, all things being equal, are larger effect sizesobtained for training programs that are evaluated by using learningversus behavioral criteria? It is important to clarify that criteriontype is not an independent or causal variable in this study. Ourobjective is to investigate whether the operationalization of thedependent variable is related to the observed training outcomes (i.e., effectiveness).

The evaluation criteria (i.e., reaction, learning, behavioral, and results) are simply different operationalizationof the effectiveness of training. Consequently, our firstresearch question is this: Are there differences in the effectivenessof training (i.e., the magnitude of the ds) as a function of theoperationalization of the dependent variable.

Fridaus categorized five determinants of service quality in higher education. They are non-academic aspect, academic aspect, reputation, access and program issues.

- Non-academic aspects: This aspect relates to the duties that carried out by non-academic staff.

- Academic aspects: It consists of the items that describe the factor that are solely the responsibilities of academics (instructor).

- Reputation: The factor consists of the item that is important for higher learning institutions in projecting a professional image.

- Access: It includes issues as approachability, ease of contact, availability and convenience of academic and non-academic staffs.

- Program issues: It includes the item related to program flexibility, offering wide range of programs/ specialization, and quality program.

Thus, conducting a systematic needs assessment is a crucialinitial step to training design and development and can substantiallyinfluence the overall effectiveness of training programs (Goldstein \& Ford, 2002; McGehee \& Thayer, 1961; Sleezer, 1993; Zemke, 1994).

A product of the needs assessment is the specification of the training objectives that, in turn, identifies or specifies the skills andtasks to be trained. A number of typologies have been offered forcategorizing skills and tasks (e.g., Gagne, Briggs, \& Wagner, 1992; Rasmussen, 1986; Schneider \& Shiffrin, 1977). Given thefair amount of overlap between them, they can all be summarizedinto a general typology that classifies both skills and tasks intothree broad categories: cognitive, interpersonal, and psychomotor (Farina \& Wheaton, 1973; Fleishman \&Quaintance, 1984; Goldstein\&Ford, 2002). One similar factor i.e. the human resource policy of training and development has been identified by Haywood (1992). He mentioned that too many training programs place emphasis on ease and the purpose behind the design of programs namely learning, skill development and behavioral change, has defeat the original purpose and goals of training are lost. Everything is affected by its surrounding weather directly or indirectly and similarly training effectiveness is also affected by many factors.

Birdi (2005) found that poor managerial support or an unfavorable departmental climate could limit the impact of creativity training with regard to influencing idea implementation. Unfavorable environment affects the training effectiveness. According to him training will be affected negatively if there is less support from department or there is unfavorable condition for training. Fischer \& Ronald (2011) stated that open-mindedness is also a significant moderator of training effectiveness. It has been found that training become more successful if the participants and trainer work with open-mindedness. Driskell (2011) concluded in his study that type of training implemented, training content and trainee expertise also affect the training outcomes. Success of a training program always depends on how the training was given, what was the content and who was the trainer.

Haslinda \& Mahyuddin (2009) found that lack of support from top management and peers, students' individual attitudes, job-related factors and also the deficiencies in training practice are the main factors which affect the effectiveness of training. If there will be less support from top management and peers, job is not going well or somehow there is problem in job and absence of training practice then there is less chance of effective training program. Beigi \& Shirmohammadi (2011) found that emotional training have significant impact on service quality. It 
means there is a relationship between behavior and learning, and service industry can be benefitted by emotional training because service industry is basically related to marketing and verbal communication.

Saks \& Haccoun (2007) discussed that psychological states of trainees especially motivation, self-efficacy, perceived control and the realities of the organizational context affects the training outcomes. Tai (2006) also concluded about general self-efficacy that it partially arbitrated the relationship between training framing and training motivation and consequently influenced training outcomes. On the other hand Black \& Mendenhall (1990) explained that cross-cultural skill development, adjustment and performance are three primary dependent variables of cross culture training effectiveness.

Research model showed that the lectures; equipment and programfactors are the independent variables but the quality of the education and training is dependent variable following.

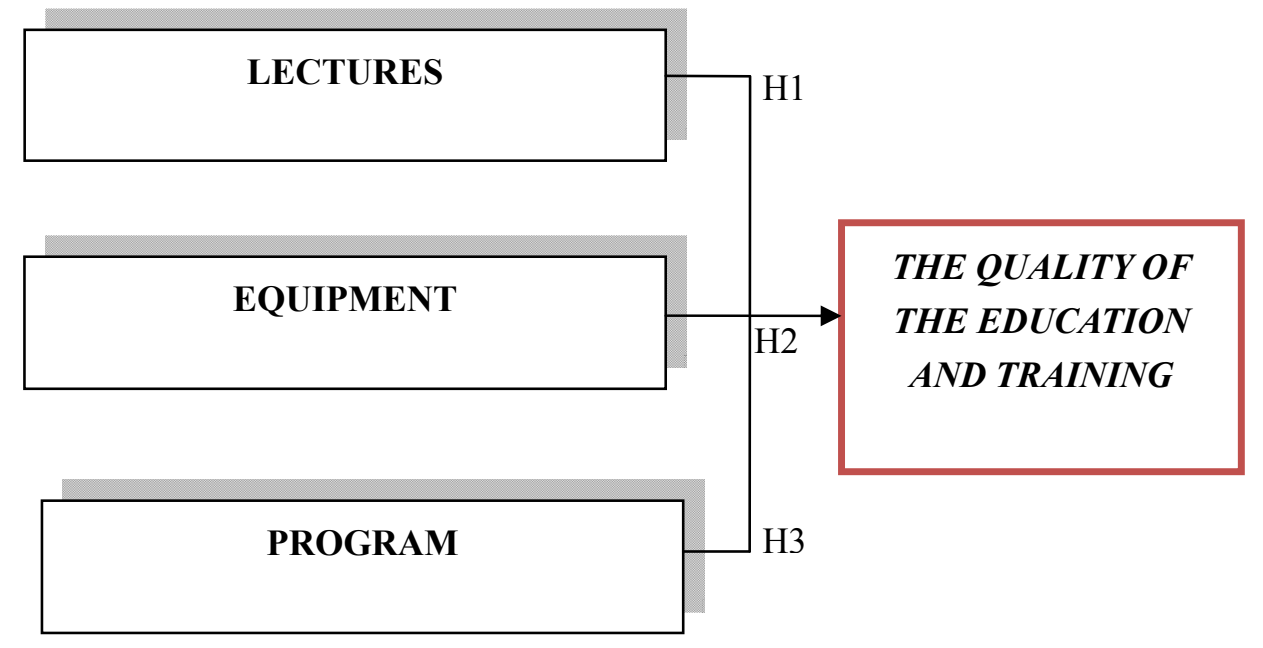

Figure 1. Research model for factors affecting the quality of the education and training

Figure 1 showed that the data collected from the questionnaire survey of 400 students at Ca Mau Community College. It analyses the participant trainees' attitudes and beliefs about the education and training quality at Ca Mau Community College.

\section{Hypothesis:}

H1: There is a positive relationship between the lecturesand the education and training quality.

$\mathrm{H} 2$ : There is a positive relationship between the equipmentand the education and training quality.

$\mathrm{H} 3$ : There is a positive relationship between the programand the education and training quality.

Definition of Quality: Quality has no specific meaning unless related to a specific function and/or object. Quality is a perceptual, conditional and somewhat subjective attribute.

Definition of Service Quality: The concept of service quality linked to the concepts of perception and expectations. Service quality perceived by the customers is the result of comparing the expectations about the service they are going to receive and their perceptions of the companys' actions (Parasuraman et al., 1988; Gronroos, 1994).

Quality in Education: The quality defined by British Standards Institution, 1978 as the totality of features and characteristic of a product or service that bear on its ability to satisfy stated or implicit needs. Quality in Education can be defined as:

The development of intellectual skills and knowledge that will equip graduates to contribute to society through productive and satisfying engineering careers as innovators, decision makers and leaders in the global economy (R. Natrajan, 1999).

Training program: Significant long-term training activity which as opposed to a training project comprises of a series of courses, and usually has a flexible time and cost budget. 
The facility: It is for adult professionals must have flexible and technologically-advanced learning environments that are safe, healthy, comfortable, aesthetically-pleasing, and accessible. It must be able to accommodate the specific space and equipment needs of the training program and curriculum. Support spaces geared toward adult needs, such as a business station that allows students to carry out some business functions during their training sessions, must be seamlessly integrated into the facility as well.

Lecturer: Lecturer is someone who stands up in front of a class and gives an organized talk designed to teach you something. There are lots of lecturers at colleges and universities.

Although many professors lecture, in this country the title lecturer usually refers to a teacher who is not a permanent member of the faculty but one of the many college instructors who does not have tenure. The lecturer may even be hired for a single semester or year. The title is used slightly differently in England. There are some professional lecturers - people, like former President Bill Clinton, who make their living by going around the world giving speeches.

\section{Research Methods}

\subsection{Methods and Techniques of the Study}

The preliminary study for traineesconducted in July 2014, using qualitative methods to interview 30 students to examine the content and meaning of the words used in the scale. Following this, the formal study conducted in July2014, using qualitative methods to interview 400students to examine the content and meaning of the words used in the scale.The researcher should select one of these methods of collecting the data taking into consideration the nature of investigation, objective and scope of the inquiry, financial resources, available time and the desired degree of accuracy.However, I should pay attention to all these factors but much depends upon the ability and experience of the researcher.

\subsection{Population and Sample of the Study}

Population is a complete set of elements (persons or objects) that possess some common characteristic defined by the sampling criteria established by the researcher.The population of this study was all studentsat $\mathrm{Ca}$ Mau Community Collegethat the values of the random variable of interest could possibly be determined. This notion corresponds directly to the frame in sample survey literature.

\subsection{Research Instrument}

Instruments used to gauge some quality or ability of your subjects. The purpose of the instrument is to elicit the data for your study. The main research method that applied in this study is quantitative research.According to McDonough (1997, cited in Sia, 2011), traditionally, educationalresearchers prefer the quantitative approach for the field of university choice. Actually, a high number of previous researchers like Joseph and Joseph (1998), Priceet al. (2003), and Sia (2011), just a few to name, have successfully appliedquantitative method. Qualitative method used to explore any new factors affecting the effectiveness of the companies' training programs.Besides, the questions for interview consisted of several open-endedquestions mainly asking whom and what influenced students during the selection of the companies. The findings from qualitative research would add to the input ofquestionnaire design in the quantitative research. Then the first draft of thequestionnaire designed and went through a pilot test to check thecomprehensibility and wording of the questions.Next, the quantitative research conducted with the final version of thequestionnaire. The quantitative method used to collect data to answer researchquestions.Investigate each tool below and complete my planning guide if the researcher chooses to use that specific instrumentation in my study. Be sure to specify if the researcher use it qualitatively or quantitatively.

\subsection{Data Gathering Procedure}

There are different data gathering procedures that I can use for this research. It depends on your convenience and the ease in gathering the required details that you can use for the research results. In any case, we discuss some of the major types of data gathering procedures. The instrument for data collection was a self-administrated questionnaire. The questionnaire designed to ascertain the demographic profile of the students. The factors influence the quality of education and training. Besides, the researcherwanted to get the information, the researcher visited to interview 400students to answer the survey questionnaire. The actual number of respondents in this research is 400 students at $\mathrm{Ca}$ Mau Community College. In addition, the data collected and analyzed using the statistical indicators with data processing software SPSS 20.0. The targets include descriptive statistics, reliability analysis, correlation analysis, explorefactor analysis, analyze multiple linear regression. 


\subsection{Data Processing}

The term of data processoftenused more specifically in the context of a business or other organization to refer to the class of commercial data processing applications,the data collected by the researcher and be analyzed by SPSS. Before having analyzed, the data screened to delete outliners to secure reliability. Creative Research Systems offers complete data processing services. We provide presentation-quality tables, text reports and graphics. There are more than 2.000 the students of the Ca Mau Community College. The researcher had surveyed 200 students of economic major (Total of population is more than 1000 students). Besides, the researcher had surveyed 200 students of technology major (Total of population is more than 1000 students). After data are collected, reliable scale tested with Cranach's alpha index, and (Exploratory Factor Analysis) draws from the official scale.

\section{Research Results}

Descriptive Statistics for the profile of the quality of the education and training at Ca Mau Community College

Table 1. Factors affecting the quality of the education and training

\section{LECTURER}

LEC1: The lecturers' major, teaching methodology and knowledge are suitable for teaching the students at the colleges and the university in Vietnam

LEC2: The lecturers applying practical experience, new methods in lessons forthe students at the colleges and the university in Vietnam

LEC3: The lecturers were enthusiasm when communicating with the students at the colleges and the university in Vietnam

LEC4: The lecturers were cheerfulness when teaching the lesions at the colleges and the university in Vietnam

LEC5: The lecturers who were politeness when communicating with the students at the colleges and the university in Vietnam

LEC6: The lecturers supplied many books for reading and presentation forthe students to understand lessons at the colleges and the university in Vietnam

\section{EQUIPMENT}

EQU1: The equipment is such as room, table that were suitable for the needs of learning for the students at the colleges and the university in Vietnam

EQU2: The equipment is such as projector, computer, micro that were suitable for the needs of teaching for the students at the colleges and the university in Vietnam

EQU3: The books, textbooks and documents are very good for teaching and practicum for the students at the colleges and the university in Vietnam

EQU4: The internet system, computers and others were very good for teaching and practicum for the students at the colleges and the university in Vietnam

EQU5: The library system, practicum place and other equipment for teaching and learning for the students at the colleges and the university in Vietnam

\section{PROGRAMS}

PRO1: The training program is suitable for your job aftergraduating fromthe colleges and the university in Vietnam

PRO2: The training program supplying necessary information for your job after graduating from the colleges and the university in Vietnam

PRO3: The training program changing for enterprise demand and social need in next years

TPRO4: The training program was very interested, significant for your job and lifeafter graduating from the colleges and the university in Vietnam

\section{QUALITY OF EDUCATION AND TRAINING}

Level of Agreement

QUA1: The facility is modern and training program of the colleges and the university is updated and to meet enterprises' need
Level of Agreement

(1) (2) (3) (4) (5)

(1) (2) (3) (4) (5)

(1) (2) (3) (4) (5)

(1) (2) (3) (4) (5)

(1) (2) (3) (4) (5)
(1) (2) (3) (4) (5)
(1) (2) (3) (4) (5)

(1) (2) (3) (4) (5)

(1) (2) (3) (4) (5)

(1) (2) (3) (4) (5)
(1) (2) (3) (4) (5)

Level of Agreement

(1) (2) (3) (4) (5)

(1) (2) (3) (4) (5)

(1) (2) (3) (4) (5)

(1) (2) (3) (4) (5)

(1) (2) (3) (4) (5) 
QUA2: Lecturer quality and teaching method is very suitable for students' job and life after graduating from the colleges and the university in Vietnam

QUA3: The knowledge, skills and behavior of students were improved in job and life after graduating from the colleges and the university in Vietnam

Source: The researcher

Some measures that are commonly used to describe a data set are measures of central tendency and measures of variability or dispersion. Measures of central tendency include the mean, median and mode, while measures of variability include the standard deviation (or variance), the minimum and maximum values of the variables.

Table 2. Descriptive statistics for the quality of the education and training

\begin{tabular}{cccccc}
\hline Code & $\mathrm{N}$ & Minimum & Maximum & Mean & Std. Deviation \\
\hline LEC1 & 367 & 1 & 5 & 3.17 & .941 \\
LEC2 & 367 & 1 & 5 & 3.20 & .934 \\
LEC3 & 367 & 1 & 5 & 3.31 & .970 \\
LEC4 & 367 & 1 & 5 & 3.37 & .934 \\
LEC5 & 367 & 1 & 5 & 3.34 & .923 \\
LEC6 & 367 & 1 & 5 & 3.30 & .931 \\
EQU1 & 367 & 2 & 5 & 3.95 & .941 \\
EQU2 & 367 & 2 & 5 & 3.90 & .956 \\
EQU3 & 367 & 1 & 5 & 3.37 & 1.103 \\
EQU4 & 367 & 2 & 5 & 3.61 & 1.290 \\
EQU5 & 367 & 1 & 5 & 3.32 & 1.343 \\
PRO1 & 367 & 1 & 5 & 3.05 & 1.039 \\
PRO2 & 367 & 1 & 5 & 3.03 & 1.013 \\
PRO3 & 367 & 1 & 5 & 3.03 & 1.012 \\
PRO4 & 367 & 1 & 5 & 3.04 & 1.035 \\
QUA1 & 367 & 2 & 5 & 3.37 & .562 \\
QUA2 & 367 & 1 & 4 & 2.37 & .563 \\
QUA3 & 367 & 2 & 5 & 4.31 & .667 \\
Valid N (listwise) & 367 & & & & \\
\hline
\end{tabular}

Source: The researcher's collecting data and SPSS

Table 2 showed that there were 400students but 367students processedat Ca Mau Community College. There were minimum value was 1 , maximum value was 5 . Standard deviationswere from 0.562 to 1.343 ; mean is from 2.37 to 4.31 but mean is around 3.0.This data was very good for regression analysis. We have 18 items and 3 components are independent variables. One componentisdependent variable.

Table 3. Descriptive statistics for gender situation

\begin{tabular}{cccccc}
\hline & Gender situation & Frequency & Percent & Valid Percent & $\begin{array}{c}\text { Cumulative } \\
\text { Percent }\end{array}$ \\
\hline \multirow{3}{*}{ Valid } & Male & 151 & 41.1 & 41.1 & 41.1 \\
& Female & 216 & 58.9 & 58.9 & 100.0 \\
& Total & 367 & 100.0 & 100.0 & \\
\hline
\end{tabular}

Source: The researcher's collecting data and SPSS

Table 3 showed that the result of the descriptive statistics from Gender situation had367students processed at Ca Mau Community Collegeinterviewed from 7/2013 to 10/2014. There were 151 male students with $41.1 \%$ and 216 female students with $58.9 \%$.

We had the result of descriptive statistics from age following: 
Table 4. Descriptive statistics for age

\begin{tabular}{llcccc}
\hline \multicolumn{1}{c}{ Age } & Frequency & Percent & Valid Percent & $\begin{array}{c}\text { Cumulative } \\
\text { Percent }\end{array}$ \\
\hline \multirow{3}{*}{ Valid } & From 18 to 20 years old & 122 & 33.2 & 33.2 & 33.2 \\
& Over 20 years old & 245 & 66.8 & 66.8 & 100.0 \\
Total & 367 & 100.0 & 100.0 & \\
\hline
\end{tabular}

Source: The researcher's collecting data and SPSS

Table 4 showed that the result of the descriptive statistics from genderhad367students processed at Ca Mau Community Collegeinterviewed from 7/2013 to 10/2014. 122 students are from 18 to 20 years old with $33.2 \%$ and 245 students who are over 20 years old with $66.8 \%$.

Table 5. Descriptive statistics for the Students information

\begin{tabular}{|c|c|c|c|c|c|}
\hline & tudents information & Frequency & Percent & Valid Percent & $\begin{array}{c}\text { Cumulative } \\
\text { Percent }\end{array}$ \\
\hline \multirow{4}{*}{ Valid } & First year & 30 & 8.2 & 8.2 & 8.2 \\
\hline & Second year & 88 & 24.0 & 24.0 & 32.2 \\
\hline & Third year & 249 & 67.8 & 67.8 & 100.0 \\
\hline & Total & 367 & 100.0 & 100.0 & \\
\hline
\end{tabular}

Source: The researcher's collecting data and SPSS

Table 5 showed that the result of the descriptive statistics from the Students informationhad367students processed at Ca Mau Community Collegeinterviewed from 7/2013 to 10/2014. There were 30First yearstudents with $8.2 \%$ and 88Second yearstudentswith $24.0 \%$. Third year had 249students with $67.8 \%$.

Table 6. Descriptive statistics for study major

\begin{tabular}{|c|c|c|c|c|c|}
\hline & Study major & Frequency & Percent & Valid Percent & $\begin{array}{c}\text { Cumulative } \\
\text { Percent }\end{array}$ \\
\hline \multirow{3}{*}{ Valid } & Economic major & 119 & 32.4 & 32.4 & 32.4 \\
\hline & Other majors & 248 & 67.6 & 67.6 & 100.0 \\
\hline & Total & 367 & 100.0 & 100.0 & \\
\hline
\end{tabular}

Source: The researcher's collecting data and SPSS

Table 6 showed that the result of the descriptive statistics from Study major had 367students processed at Ca Mau Community College interviewed from 7/2013 to 10/2014. There were 119studentsstudying Economic majorwith $32.4 \%$ and 248 studentsstudyingother majors with $67.6 \%$.

Evaluate the reliability of the scale of the quality of the education and training

Table 7. Results of analysis of Cronbach Alpha coefficients

\begin{tabular}{cccccc}
\hline \multirow{2}{*}{ Indicators } & & $\begin{array}{l}\text { Average scale if } \\
\text { removal } \\
\text { variables }\end{array}$ & $\begin{array}{l}\text { Scale variance if } \\
\text { the removal } \\
\text { variables }\end{array}$ & $\begin{array}{l}\text { The } \\
\text { correlation } \\
\text { coefficient of } \\
\text { the total } \\
\text { variations }\end{array}$ & $\begin{array}{l}\text { Cronbach alpha } \\
\text { coefficient if the } \\
\text { removal } \\
\text { variables }\end{array}$ \\
\hline \multirow{3}{*}{ LECTURER } & LEC1 & 16.52 & 15.256 & .785 & .889 \\
\cline { 2 - 7 } & LEC2 & 16.49 & 15.841 & .700 & .901 \\
\cline { 2 - 7 } & LEC3 & 16.38 & 15.281 & .750 & .894 \\
\hline & LEC4 & 16.32 & 15.826 & .701 & .901 \\
\hline
\end{tabular}




\begin{tabular}{|c|c|c|c|c|c|}
\hline & LEC5 & 16.36 & 15.329 & .793 & .888 \\
\hline & LEC6 & 16.39 & 15.408 & .771 & .891 \\
\hline \multicolumn{6}{|l|}{ Alpha $=0.910$} \\
\hline \multirow{5}{*}{ EQUIPMENT } & EQU1 & 14.20 & 17.573 & .905 & .908 \\
\hline & EQU2 & 14.26 & 17.759 & .859 & .915 \\
\hline & EQU3 & 14.79 & 17.429 & .755 & .930 \\
\hline & EQU4 & 14.55 & 15.456 & .836 & .917 \\
\hline & EQU5 & 14.83 & 15.062 & .837 & .919 \\
\hline \multicolumn{6}{|l|}{ Alpha $=0.933$} \\
\hline \multirow{4}{*}{ PROGRAM } & PRO1 & 9.10 & 7.892 & .749 & .907 \\
\hline & $\mathrm{PRO} 2$ & 9.13 & 7.580 & .849 & .872 \\
\hline & $\mathrm{PRO} 3$ & 9.12 & 8.031 & .748 & .907 \\
\hline & PRO4 & 9.11 & 7.384 & .868 & .864 \\
\hline \multicolumn{6}{|l|}{ Alpha $=0.913$} \\
\hline \multirow{3}{*}{$\begin{array}{c}\text { QUALITY OF } \\
\text { EDUCATION } \\
\text { AND TRAINING }\end{array}$} & QUA1 & 6.68 & 1.342 & .931 & .867 \\
\hline & QUA2 & 7.68 & 1.343 & .929 & .868 \\
\hline & QUA3 & 5.74 & 1.262 & .778 & .998 \\
\hline
\end{tabular}

Source: The researcher's collecting data and SPSS

The above results of the Table 7 revealed that all of components are very good for this research. Continue author analyzed the EFA to assess more accurately the scale, helping the uniform scale in research. Thus, based on the authors EFA analysis will evaluate the homogeneity of the observed variables and can be classified because of specific variables.

$\mathrm{KMO}$ and Bartlett's Test for the quality of the education and training

KMO \& Bartlett's test play an important role for accepting the sample adequacy. While the KMO ranges from 0 to 1 , the world-over accepted index is over 0.6. For Factor Analysis recommended suitable, the Bartlett's Test of Sphericity must be less than 0.05 .

Table 8. KMO and Bartlett's Test for the quality of the education and training

\begin{tabular}{llc}
\hline Kaiser-Meyer-Olkin Measure of Sampling Adequacy. & .796 \\
& Approx. Chi-Square & 5403.535 \\
Bartlett's Test of & df & 105 \\
Sphericity & Sig. & .000 \\
\hline
\end{tabular}

\begin{tabular}{ccccccc}
\hline Comp. & \multicolumn{3}{c}{ Initial Eigenvalues } & \multicolumn{3}{c}{ Extraction Sums of Squared Loadings } \\
\cline { 2 - 7 } & Total & \% of Variance & Cumulative \% & Total & \% of Variance & Cumulative \% \\
\hline 1 & 4.680 & 31.202 & 31.202 & 4.680 & 31.202 & 31.202 \\
2 & 3.958 & 26.385 & 57.587 & 3.958 & 26.385 & 57.587 \\
3 & 2.763 & 18.423 & 76.010 & 2.763 & 18.423 & 76.010 \\
4 & .893 & 5.951 & 81.962 & & & \\
5 & .619 & 4.127 & 86.089 & & & \\
6 & .430 & 2.869 & 88.958 & & & \\
7 & .350 & 2.330 & 91.288 & & &
\end{tabular}




$\begin{array}{cccc}8 & .313 & 2.084 & 93.372 \\ 9 & .305 & 2.036 & 95.408 \\ 10 & .263 & 1.757 & 97.165 \\ 11 & .165 & 1.101 & 98.266 \\ 12 & .079 & .527 & 98.793 \\ 13 & .064 & .429 & 99.221 \\ 14 & .062 & .416 & 99.637 \\ 15 & .054 & .363 & 100.000\end{array}$

Source: The researcher's collecting data and SPSS

Table 8 showed that Kaiser-Meyer-Olkin Measure of Sampling Adequacy was statistically significantandhigh datareliability $(\mathrm{KMO}=0.796>0.6)$. This result was very good for data analysis. Table 8 showed that Cumulative percent was statistically significantandhigh datareliabilitywas $76.010 \%$ (> $60 \%)$.

Structure Matrixfor factors of the quality of the education and training

Table 9. Structure Matrix for factors for the quality of the education and training

\begin{tabular}{lccc}
\hline Code & \multicolumn{3}{c}{ Component } \\
\cline { 2 - 4 } & 1 & 2 & 3 \\
\hline LEC5 & .865 & & \\
LEC1 & .856 & & \\
LEC6 & .852 & & \\
LEC3 & .830 & & \\
LEC4 & .793 & & \\
LEC2 & .788 & & \\
EQU1 & & .959 & \\
EQU2 & & .928 & \\
EQU5 & & .895 & \\
EQU4 & & .881 & \\
EQU3 & & .832 & .933 \\
PRO4 & & & .912 \\
PRO2 & & & .867 \\
PRO1 & & & .850 \\
PRO3 & & & \\
\hline
\end{tabular}

Source: The researcher's collecting data and SPSS

Table 9 showed that Structure Matrix for the factors affecting the quality of the education and training at $\mathrm{Ca}$ Mau Community Collegehad 3Components. Component 1 (X1) was Lecturer, Component 2 (X2) was Facilities, Component 3 (X3) was program.

Table 10. Structure Matrix for the quality of the education and training

KMO and Bartlett's Test

\begin{tabular}{|c|c|c|c|c|c|c|}
\hline \multicolumn{4}{|c|}{ Kaiser-Meyer-Olkin Measure of Sampling Adequacy. } & .689 & & \\
\hline & & \multicolumn{2}{|c|}{$\begin{array}{l}\text { of Sampling Adequacy. } \\
\text { Approx. Chi-Square }\end{array}$} & 2071.591 & & \\
\hline \multicolumn{2}{|c|}{ Bartlett's Test of Sphericity } & \multirow{2}{*}{$\begin{array}{l}\text { df } \\
\text { Sig. }\end{array}$} & & 3 & & \\
\hline & & & & .000 & & \\
\hline \multicolumn{7}{|c|}{ Total Variance Explained } \\
\hline \multirow[t]{2}{*}{ Component } & \multicolumn{3}{|c|}{ Initial Eigenvalues } & \multicolumn{3}{|c|}{ Extraction Sums of Squared Loadings } \\
\hline & Total & $\%$ of Variance & Cumulative $\%$ & Total & $\begin{array}{c}\% \text { of } \\
\text { Variance }\end{array}$ & Cumulative $\%$ \\
\hline 1 & 2.704 & 90.145 & 90.145 & 2.704 & 90.145 & 90.145 \\
\hline 2 & .291 & 9.711 & 99.857 & & & \\
\hline 3 & .004 & .143 & 100.000 & & & \\
\hline
\end{tabular}




\begin{tabular}{cc}
\hline \multirow{2}{*}{$\begin{array}{c}\text { Extraction Method: Princi } \\
\text { Component Matrix }\end{array}$} \\
\hline Code & Component \\
\cline { 2 - 2 } & 1 \\
\hline QUA1 & .978 \\
QUA2 & .977 \\
QUA3 & .891 \\
\hline
\end{tabular}

Source: The researcher's collecting data and SPSS

Table 10 showed that KMO and Bartlett's Test for the quality of the education and training at Ca Mau Community Collegeshowed that Kaiser-Meyer-Olkin Measure of Sampling Adequacy was statistically significantandhigh datareliability $(\mathrm{KMO}=0.689>0.6)$. This result was very good for data analysis. the quality of the education and training at $\mathrm{Ca}$ Mau Community Collegeshowed that Cumulative percent was statistically significantandhigh datareliabilitywas $90.145 \%$ ( $>60 \%$ ). Note: the quality of the education and training $(\mathrm{Y})$ is dependent variable.

Regression analysis for factors affecting the quality of the education and trainingat $\mathrm{Ca}$ Mau Community College

Table 11. Testingfor factors affecting the quality of the education and training

\begin{tabular}{|c|c|c|c|c|c|c|}
\hline \multicolumn{6}{|c|}{ Model Summary $^{\mathbf{b}}$} & \\
\hline Model & $\mathrm{R}$ & R Square & $\begin{array}{l}\text { Adjusted R } \\
\text { Square } \\
\end{array}$ & $\begin{array}{l}\text { Std. Error of the } \\
\text { Estimate }\end{array}$ & Durbin-Watson & \\
\hline 1 & $.697^{\mathrm{a}}$ & .485 & .481 & .72050781 & 1.723 & \\
\hline \multicolumn{7}{|c|}{$\begin{array}{l}\text { a. Predictors: (Constant), X3, X1, X2 } \\
\text { b. Dependent Variable: } \mathrm{Y}\end{array}$} \\
\hline Model & & Sum of Squares & $\mathrm{df}$ & Mean Square & $\mathrm{F}$ & Sig. \\
\hline \multirow{3}{*}{1} & Regression & 177.555 & 3 & 59.185 & 114.008 & $.000^{\mathrm{b}}$ \\
\hline & Residual & 188.445 & 363 & .519 & & \\
\hline & Total & 366.000 & 366 & & & \\
\hline
\end{tabular}

a. Dependent Variable: Y

b. Predictors: (Constant), X3, X1, X2

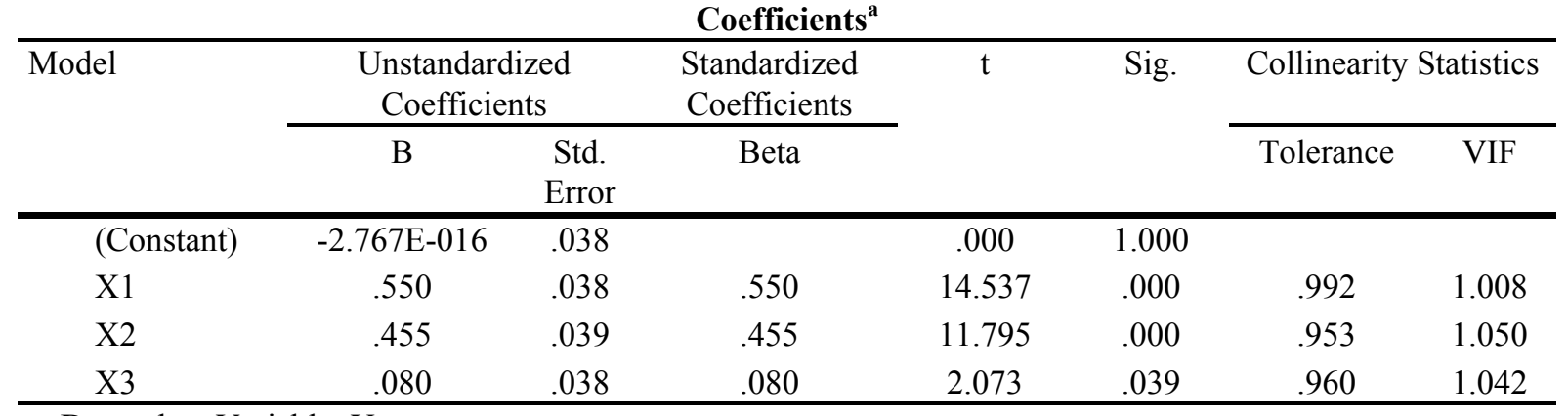

a. Dependent Variable: Y

Source: The researcher's collecting data and SPSS

Table 11 showed that Adjusted R Square was statistically significantandhigh datareliability. In addition, Adjusted R Squarereached $48.1 \%$.Resultsshowed that all $\mathrm{t}$ value $>2$ was statistically significantandhigh datareliability. Besides, theregression coefficientswere positive. This showed thattheeffectsof independent variablesin the same directionwith the quality of the education and training at $\mathrm{Ca}$ Mau Community College.

Component 1 (X1):Lecturerfactor affecting onthe quality of the education and training at $\mathrm{Ca}$ Mau Community College with significance level of $5 \%$.

Component 2(X2):Facilitiesfactor affecting on the quality of the education and training at Ca Mau Community College with significance level of $5 \%$. 
Component 3 (X3):Programfactor affecting on the quality of the education and training at Ca Mau Community College with significance level $5 \%$.

Variance Inflation Factor (VIF) and Tolerance are two measures that can guide aresearcher in identifying MC. Before developing the concepts, it should be noted that thevariance of the OLS estimator for a typical regression coefficient shownto be the following $\mathrm{VIF}<10$. $(1<\mathrm{VIF}<10)$. This showed that there was not Multicollinearity.

The test results $\mathrm{F}=114.008$ value and Sig. $=0.000<0.05$ shows the building model is consistent with the data set and the variables included in the model which are related to the dependent variable. Generally, regression analysis with selected reliability is $99 \%$, corresponding to the selected variables are statistically significant at the $p<0.01$; the results show that all variables are satisfying the demand. Verification of conformity of the model shows multicollinearity phenomenon does not violate $(\mathrm{VIF}<10)$.

The results of regression analysis show that factors presenting the priority as follows: (1) Component 1 (X1): Lecturer: $\beta=0.550$; (2) Component 2 (X2): Facilities: $\beta=0.455$; (3) Component 3 (X3): Program: $\beta=0.080$. This is standardized coefficients of beta.

Model summary analysis for factors affecting the quality of the education and trainingat $\mathrm{Ca}$ Mau Community College

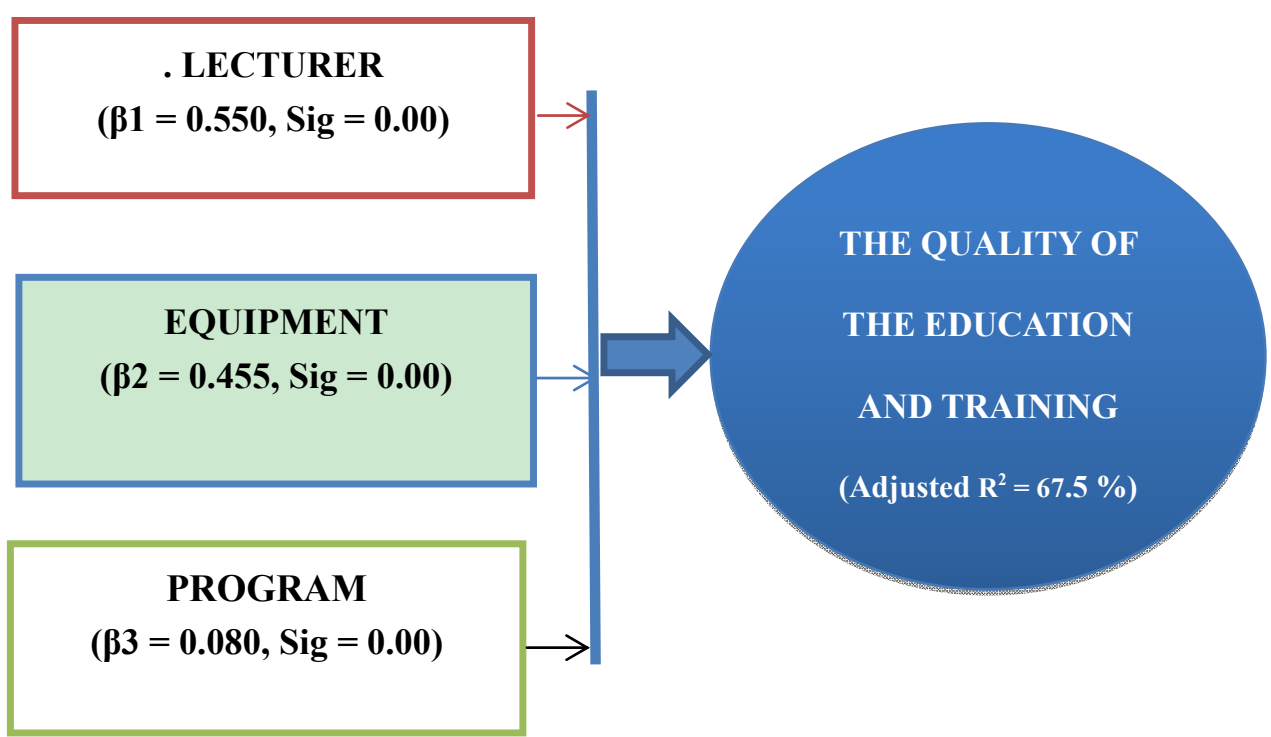

Figure 2. The Resultof the Regressionforfactors affecting the quality of the education and training at Ca Mau Community College

Figure 2 showed that theregression coefficientswere positive. This showed thattheeffectsof independent variables are in the same directionto the quality of the education and trainingat $\mathrm{Ca}$ Mau Community Collegewith significancelevel of $5 \%$.

The Result of the Regression Standardized Residual for the quality of the education and training at $\mathrm{Ca}$ Mau Community College 

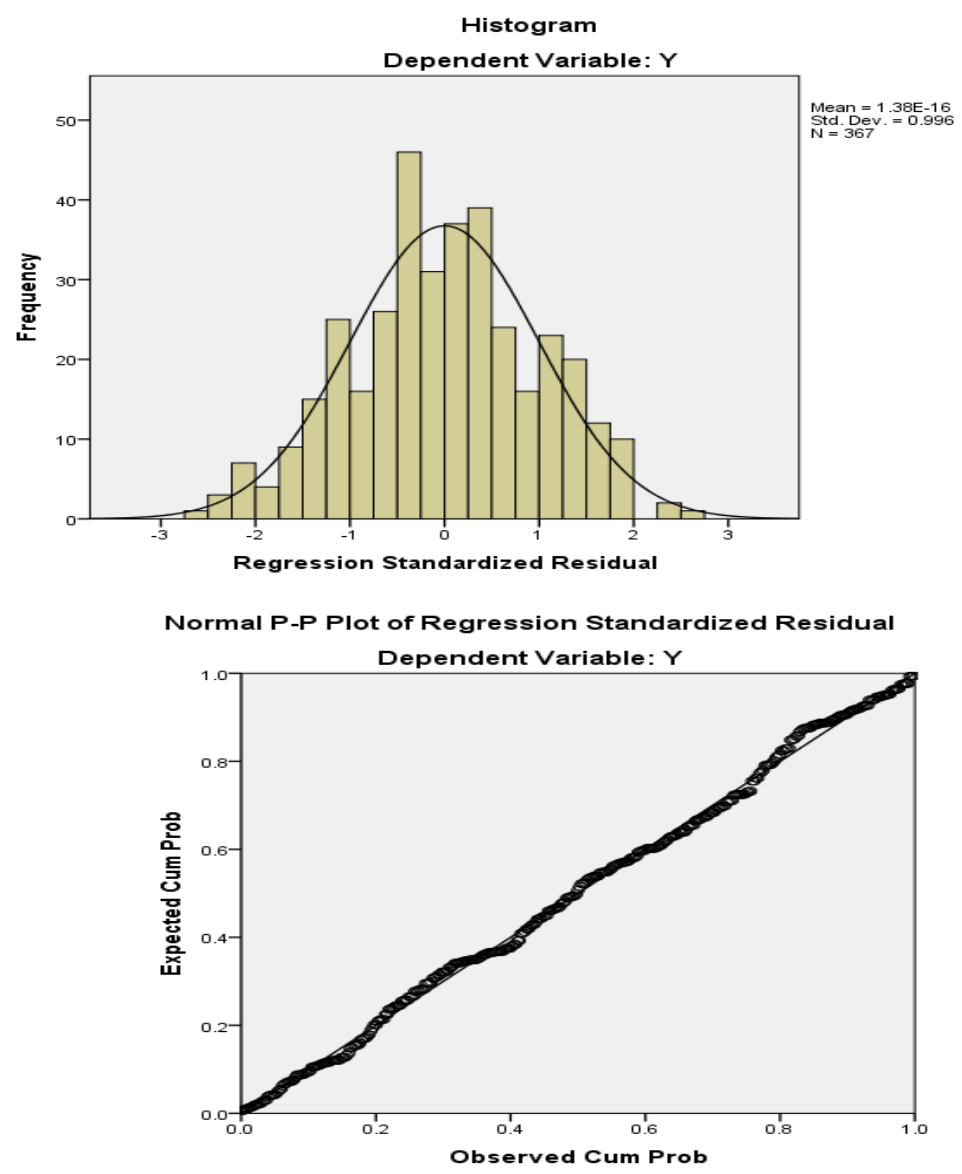

Figure 3. The Result of the RegressionStandardizedResidualof the quality of the education and training

Figure 3 showed that the standardized residual of the quality of the education and trainingwas normal distribution $($ Standard deviation $=0.995$, nearly $=1)$.

Table 12. Bootstrap results based on 1000 bootstrap for the quality of the education and training

Bootstrap for Model Summary

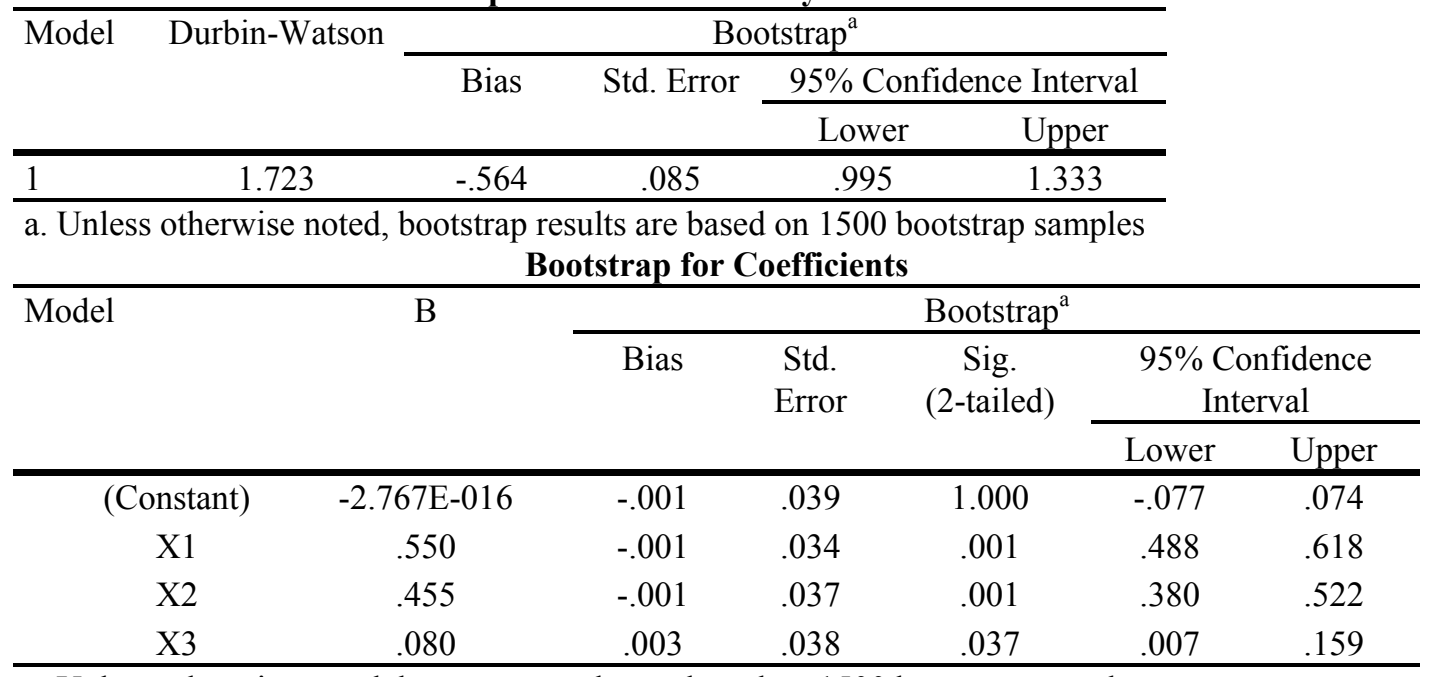

a. Unless otherwise noted, bootstrap results are based on 1500 bootstrap samples

Source: The researcher's collecting data and SPSS 
Table 12 showed that Bootstrap is an alternative to asymptotic approximation for carrying out inference. This showed that there were the same results of the regression for the quality of the education and training at Ca Mau Community College with significance level of $5 \%$.Table 12 showed that Sig value was statistically significant and Significance value is $0.000(<0.05)$. The results presented with the observed $t$-value, the degrees of freedom, and the statistical significance of the one-sample t-test orSig $<0.05$. Therefore, it concluded that the population means are statistically significantly different. If $\mathrm{Sig}>0.05$. There was the difference between the sample-estimated population mean. Therefore, this result showed that there was no the difference between the sample-estimated population mean with significance level of $5 \%$.

Table 13. Analysis of Variance (ANOVA) about gender situation

\begin{tabular}{lccccc}
\hline \multicolumn{1}{c}{ Gender } & Sum of Squares & df & Mean Square & F & Sig. \\
\hline Between Groups & 1.245 & 1 & 1.245 & 1.245 & .265 \\
Within Groups & 364.755 & 365 & .999 & & \\
Total & 366.000 & 366 & & & \\
\hline
\end{tabular}

Source: The researcher's collecting data and SPSS

Table 13 showed that Analysis of Variance (ANOVA) about Gender situation showed that $\mathrm{F}=1.245$ was statistically significant and Significance valuewas 0.265(>0.05). Therefore,we reject $\mathrm{H}_{1}$ and accept $\mathrm{H}_{0}$. This showed that there was no different from Gender situation for the assessing aboutthe quality of the education and training at $\mathrm{Ca} \mathrm{Mau}$ Community College with significance level of $5 \%$.

Table 14. Analysis of Variance (ANOVA) about age

\begin{tabular}{lccccc}
\hline \multicolumn{1}{c}{ Age } & Sum of Squares & df & Mean Square & F & Sig. \\
\hline Between Groups & .012 & 1 & .012 & .012 & .912 \\
Within Groups & 365.988 & 365 & 1.003 & & \\
Total & 366.000 & 366 & & & \\
\hline
\end{tabular}

Source: The researcher's collecting data and SPSS

Table 14 showed that Analysis of Variance (ANOVA) about Ageshowed that $\mathrm{F}=0.012$ was statistically significant and Significance valuewas 0.912(>0.05). Therefore,we reject $\mathrm{H}_{1}$ and accept $\mathrm{H}_{0}$. This showed that there was no different from Agefor the assessing about the quality of the education and training at $\mathrm{Ca}$ Mau Community Collegewith significance level of $5 \%$.

Table 15. Analysis of Variance (ANOVA) about students information

\begin{tabular}{lccccc}
\hline Students information & Sum of Squares & df & Mean Square & F & Sig. \\
\hline Between Groups & 4.253 & 2 & 2.127 & 2.140 & .119 \\
Within Groups & 361.747 & 364 & .994 & & \\
Total & 366.000 & 366 & & & \\
\hline
\end{tabular}

Source: The researcher's collecting data and SPSS

Table 15 showed that Analysis of Variance (ANOVA) about Students informationshowed that $\mathrm{F}=2.140$ was statistically significant and Significance valuewas $0.119(>0.05)$. Therefore,we reject $\mathrm{H}_{1}$ and accept $\mathrm{H}_{0}$. This showed that there was no different from Students informationfor the assessing about the quality of the education and training at $\mathrm{Ca}$ Mau Community Collegewith significance level of $5 \%$.

Table 16. Analysis of Variance (ANOVA) about the Study major

\begin{tabular}{cccccc}
\hline The Study major & Sum of Squares & $\mathrm{df}$ & Mean Square & F & Sig. \\
\hline Between Groups & .575 & 1 & .575 & .575 & .449
\end{tabular}




\begin{tabular}{llll} 
Within Groups & 365.425 & 365 & 1.001 \\
Total & 366.000 & 366 & \\
\hline
\end{tabular}

Source: The researcher's collecting data and SPSS

Table 16 showed that Analysis of Variance (ANOVA) about the Study majorshowed that $\mathrm{F}=0.575$ was statistically significant and Significance valuewas 0.449(>0.05). Therefore,we reject $\mathrm{H}_{1}$ and accept $\mathrm{H}_{0}$. This showed that there was no different from the Study majorfor the assessing about the quality of the education and training at $\mathrm{Ca}$ Mau Community Collegewith significance level of $5 \%$.

\section{Conclusions}

Improving the quality of education and training is one of the most important tasks to ensure success progress fundamental and comprehensive change education in Vietnam under General Assembly Resolution XI the National Party. To improve the quality of training requires cognitive perspective, strategy development suitable and reasonable solutions.

The research results showed that there were 400students belong to $\mathrm{Ca}$ Mau Community Collegewho to be interviewed and answered nearly 18 questions. The researcher had analyzed KMO test, the result of KMO analysis used for multiple regression analysis. Studentsare responses measured through an adapted questionnaire on a 5-point Likert scale. Hard copy and interviewstudentsby questionnaire distributed among students of Ca Mau Community College. The regression analysis result showed that there were threefactors, which included of factors followinglecturer, equipmentandprogramsaffecting the education and training quality at Ca Mau Community College with significance level of $5 \%$. In addition. The research result processed from SPSS 20.0 software. The parameters of the model estimated by Least - Squares Method tested for the model assumption with 5\% significance level. At the same time, the result was also scientific evidence and important for researchers, and policy makers who apply them for improving the education and training quality and developing human resource management in both $\mathrm{Ca}$ Mau province and other provinces.

\section{References}

Aaron W. Hughey, \& Kenneth J. Mussnug. (1997). Designing effective employee training programmes. Training for Quality.

Afzaal Ali, \& Israr Ahmad. Key Factors for Determining Students' Satisfaction in Distance Learning Courses: A Study of AllamaIqbal Open University, And International Islamic University, Pakistan.

AharonTziner. (2007). Effects of Trainee Characteristics on Training Effectiveness. International Journal of Selection and Assessment.

Ahrens, L., \& Kemmerer, F. (2002). Higher education development. Cambodia Development Review.

Atnafu, B., \& M. Eshete. (2004). Quality of Education in Private and Public Higher Education Institutions. A Comparative Analysis. Proceedings of the 2nd National Conferences on Private Higher Education in Ethiopia, Addis Ababa, Sheraton Addis.

B.K. Punia. (2013). Conducted a study on "A review of factors affecting training effectiveness vis-à-vis managerial implications and future research directions".

Berg, B. (2001). Qualitative research methods for the social sciences. Boston:Allyn and Bacon.

Chalchisa, D. (2006). Integrating Teaching and Research to Enhance the Quality of Education. Journal of Education for Development.

Cheng, Y. C., \& Tam, M. M. (1997). Multi-Model of quality in education. Quality Assurance in Education.

Collis, J., \& Hussey, R. (2003). Business Research: A Practical Guide for Undergraduate and Postgraduate Student. Basingstoke, Palgrave MacMillan.

David DiBiase, John. (2005). The impact of increasing enrollment on faculty workload and student satisfaction over time. Dutton e-Education Institute, College of Earth and Mineral Sciences.

David W. Letcher. Determinants of undergraduate business student satisfaction. The College of New Jersey.

Eraut, M., Alderton, J., Cole, G., Senker, P. (1998). Development of Knowledge and Skills in Employment, University of Sussex Institute of Education. Brighton, Research Report. 
Fisher, C. (2004). Researching and Writing a Dissertation for Business Students. Harlow, FT Prentice Hall.

Harvey, L., \& Green, D. (1993). Assessment and Evaluation in Higher Education.

Hassan Shahid. (2012). What Factors Affect a Student's Choice of a University for Higher Education? Forman Christian College, Pakistan.

Jason Scott Edwards. (2013). Conducted a study on "Factors affecting Training transfer in Supervisors and Hourly Students in a Manufacturing Organization".

Keisuke Hirano. (2008). Decision theory in econometrics. The New Palgrave Dictionary of Economics.

Kennedy, Peter. (2003). A guide to econometrics. Cambridge, Mass: MIT Press.

Kirkpatrick, D. L., \& Kirkpatrick, J. D. (2010). Evaluating training programs. The four levels (3 ed.). USA: Berrett-Koehler Publishers.

Melissa M. Vito. The impact of faculty-student interaction outside of classroom on faculty satisfaction, engagement, and retention. Northern Arizona University.

Merriam, S. (1998). Qualitative research and case study applications in education. SanFrancisco.

Mohd Yazam Shariff. (2008). Conducted a study on "Factors Affecting Training Effectiveness. A Study of Semiconductor Wafer Fabrication Industry in Malaysia".

Muhammed Ehsan Malik. The Impact of Service Quality on Students' Satisfaction in Higher Education Institutes of Punjab. University of the Punjab, Pakistan.

Rafael A. Calvo. Factors affecting students' experiences and satisfaction about teaching quality in Engineering. School of Electrical and Information Engineering, The University of Sydney.

S. Panchapakesan. (2012). Conducted a study on "Effectiveness of Training Transfer and Factors Influences the Training Transfer - An Analysis".

Seymour, D. T. (1993). On Causing Quality in Higher Education. Series on Higher Education, American council on Education.

Vimala Sanjeevkumar. (2011). Conducted a study on "A Study on Training Factors and Its Impact on Training Effectiveness in Kedah State Development Corporation, Kedah, Malaysia".

Wooldridge, Jeffrey. (2003). Introductory Econometrics: A Modern Approach. Mason: Thomson South-Western.

Zaribaf. (2005). An Effective Factors Pattern Affecting Implementation of Strategic plans. Tehran, Iran. 